\title{
An Analysis of Factors affecting Learners' attitudes towards the Integration of E-learning into the Higher Education System in Libya: Case Study; Misurata University
}

\author{
Khalid Ramadan ${ }^{1}$, Jamal Elatresh ${ }^{2}$, Alzain Alzain ${ }^{3}$, Umit Tokeser $^{4}$ \\ ${ }^{1}$ Department of Computer Science, Institute of Materials and Engineering, Kastamonu University/Turkey \\ ${ }^{2}$ Department of Computer Science, Institute of Materials and Engineering, Kastamonu University/Turkey \\ ${ }^{3}$ Department of Computer Science, Faculty of Education, Misurata University/Libya \\ ${ }^{4}$ Department of Mathematics, Faculty of Science and letters, Kastamonu University/Turkey
}

Correspondence Author: Khalid Ramadan, Department of Computer Science, Institute of Materials and Engineering, Kastamonu University/Turkey E-mail: kramadan@ogr.kastamonu.edu.tr

Received date: 15 August 2019, Accepted date: 30 September 2019, Online date: 28 October 2019

Copyright: $\odot 2019$ Khalid Ramadan et al, This is an open-access article distributed under the terms of the Creative Commons Attribution License, which permits unrestricted use, distribution, and reproduction in any medium, provided the original author and source are credited.

\begin{abstract}
Investigating the learners' attitudes towards e-learning is significant because it is a widespread technique and it enriches the understanding of the challenges of integrating such systems into the education process. Although the learners' attitudes toward e-learning in many developed countries have seen a significant amount of research, unfortunately in Libya this work is still in its infancy. Therefore, the purpose of this study is to investigate the attitude of learners in the Libyan Higher Education System (LHES) toward e-learning. A questionnaire methodology has been harnessed to collect data from 407 students across different colleges at Misurata University (MU), in Libya. To investigate the research hypothesizes, the collected data were analyzed using Statistical Package for Social sciences (SPSS). The results reveal that the learners at MU have a positive attitude towards e-learning. It also indicated that the attitude of learners is varied based on their academic discipline, their experience with using Information and Communication Technology (ICT) tools, and English proficiency. The results of this research might be leading to provide clear insights that could be contributing to the effective implementation of E-learning in LHES.
\end{abstract}

Keywords: Misurata University, e-learning success, learners' attitude, student' satisfaction, information and communication technology

\section{INTRODUCTION}

The vast and rapid developments of ICT technology have increased societies all over the globe dependence on ICT resources in facilitating life aspects, especially those of educational interest( Farahat, 2012; Goodwin \& Al-hunaiyyan, 2008; Rhema \& Miliszewska, 2010; Zabadi \& Al-Alawi, 2016). In this essence, one of the recent trend and significant developments in the harness of ICT in education environment has been the amalgamation of e-learning technology as a tool to improve and support the processes of teaching and learning(Tarhini, Elyas, Akour, \& Al-Salti, 2016; Xhaferi, Bahiti, \& Farizi, 2018; Zabadi \& Al-Alawi, 2016). However, despite this trend, Libyan Higher Education Institutes (LHEIs) are still struggling with conventional face-to-face of teaching and learning method(Alzain, Clark, \& Ireson, 2014; Othman, Pislaru, Kenan, \& Impes, 2013a; Ramadan, Elatresh, Alzain, \& Tokeser, 2019; Rhema \& Miliszewska, 2010). LHEIs have lagged behind those in the industrialized world, chiefly due to numerous socio-economic challenges and drawbacks like obsolete ICT infrastructure and the end-user acceptance of e-learning technology, including the perceptions and engagement (Almansuri \& Elmansuri, 2015; Kenan \& Pislaru, 2012; Othman, Pislaru, Kenan, \& Impes, 2013b; Rhema \& Miliszewska, 2010; Tamtam, Gallagher, Olabi, \& Naher, 2011).

Currently, in Libyan society, the education system is viewed as a pivotal sector for re-developing and flourishing the country. In light of this, MU, as well as some other LHEIs, has recognized the significance of harnessing e-learning as a new paradigm to achieve an enhancement in learning and teaching outcomes. As e-learning system is a student-centred approach; in which learners are the key stakeholders of all education process, various studies indicated that the effective application of teaching and learning technology depends chiefly upon the trainees' satisfaction and perceptions(Liaw, Huang \& Chen, 2007; Selim, 2007; Xaymoungkhoun, Bhuasiri, Rho, Zo, \& Kim, 2012). 
Citation: Khalid Ramadan, et al., An Analysis of Factors affecting Learners' attitudes towards the Integration of E-learning into the Higher Education System in Libya: Case Study; Misurata University. Australian Journal of Basic and Applied Sciences, 13(10): 55-64. DOI: 10.22587/ajbas.2019.13.10.8

With this concept, the objective of the present study is to examine the students' perceptions and attitudes toward e-learning and also the underlying factors that might influence these perceptions and attitudes at MU as one of HEIs in Libya.

The findings of this research may pave the way to develop a paradigm for e-learning implementation and may contribute to the field of e-learning development in Libya by exploring the main challenges that influence learners' acceptance of e-learning.

\section{Research Objectives and Questions}

The overall objective of the present research is to explore if there are significant variances of demographic profiles of MU learners on perception and attitudes towards the amalgamation of e-learning.

Research questions that guided the study;

1. What are the overall attitudes and perceptions of learners towards e-learning?

2. Is there any association between learners' attitude towards e-learning and their demographic characteristics including age, gender, ICT experience and skills, English language proficiency and academic area?

\section{LITERATURE REVIEW}

Over the past decades, e-learning has been widely accepted in the educational setting and has been regarded as an integral part of a successful educational process in many parts of the world. Nevertheless, it remains at an early stage of development, especially in developing nations(Al-Adwan, Al-Adwan \& Smedley, 2013; Bhuasiri, Xaymoungkhoun, Zo, Rho, \& Ciganek, 2012; Rhema \& Miliszewska, 2010). Regarding the HEIs context in developing countries, they confront unique challenges compared to industrialized states (Bhuasiri et al., 2012; Kasse \& Balunywa, 2013).Those challenges including : the lack the necessary ICT infrastructure and resources (Al-Azawei, Parslow, \& Lundqvist, 2016; Idris \& Osman, 2017; Kisanga \& Ireson, 2015; Mwakyusa \& Mwalyagile, 2016); and the conventional methods dominant in teaching and learning practice (Andersson \& Grönlund, 2009); and, the absence the capability to launch innovative teaching and learning initiatives on their own (Andersson \& Grönlund, 2009). More significantly, understanding learners' awareness, acceptance and readiness of e-learning adoption(Al-Gahtani, 2016; Farahat, 2012; Xhaferi, Bahiti \& Farizi, 2018; Zabadi \& Al-Alawi, 2016). According to Pilli, "many universities that applied Elearning services faced many difficulties in terms of adopting successful scenarios including the acceptance and effectiveness of delivering courses" (Pilli, Fanaeian \& Al-Momani, 2014,p.169).

In this connection, Saade, reported that "in general, like any information systems, user acceptance and usage are important primary measures of system success" (Saade, Nebebe \& Tan, 2007, p.176).

Strong support can be found for this argument by Al- Adwan who reported that the amalgamation of ICT in the learning practice must be preceded by the learner acceptance; otherwise, this process would be ostracized and eventually would fail(AlAdwan et al., 2013).

There are some significant aspects for the implementation of e-learning efficiently, however, a comprehensive grasp of the end-user acceptance is the most considerable phase toward developing and deploying a successful e-learning initiative (ŽuvićButorac, M., Rončević, N., Nemčanin, D., \& Nebić \& Žuvic-Butorac, 2011).In light of this, it is a fundamental issue to know how learners perceive and take part in an e-learning setting along with how to establish an efficient e-learning paradigm to enrich the learning practice. (Koohang \& Durante, 2003).Moreover, examining students' intentions and exploring the factors that might influence on learers' beliefs about e-learning could contribute to evolving modern techniques for increasing the usability and quality of the ICT resources, and this may also appealing learners who keen with e-learning systems(Park, 2009; Rahamat, Shah, \& Din, 2012).Therefore, it is a core issue to explore aspects that clarify students' acceptance, intention and attitude towards utilizing e-learning technology (Al-Adwan et al., 2013). In this essence, addressing those challenges requires more exploration of the factors influencing successful deployment of e-learning including learners' awareness and attitudes as an essential determinant or prerequisite for any successful initiatives(Ahmed, 2013; Pilli et al.,2014; Zabadi \& Al-Alawi, 2016).

According to Cowen, adopting new technology that is not accepted and utilized by user effectively, such as online learning, is a waste of resources including time, money and effort(Cowen, 2009). Similarly, Pilli, highlighted that "As technology becomes more integral to the function of educational organizations as a whole, the ability of students to integrate new technology into their learning process becomes an ever-larger determinant of success" (Pilli et al.,2014,p.169).

As many researchers think that the successful amalgamation of ICT in education is associated with the essential factors regarding the acceptance and effectiveness of delivering instructional materials and teaching activities as well as end-user satisfaction (Eke Helen Nneka, 2011; Farahat, 2012; Pilli et al.,2014; Zabadi \& Al-Alawi, 2016) .Thus, positive attitude towards ICT adoption is extensively perceived to be as a pivotal determinant for the effective deployment of e-learing (Sife, Lwoga, Sanga, 2007; Woodrow, 1990) and also more understanding to and recognition of the user's attitudes toward e-learning is a significant step for the production of appropriate e-learning environments for efficient teaching and learning practices (Kenan, Pislaru, \& Elzawi, 2012). There is a similar opinion evoked by some researchers(Chen, 2010; Park, 2009; Zhang, Zhao, \& ..., 2004) affirmed that the degree of learners' satisfaction and attitudes have a significant and an essential direct influence on adopting e-learning; yet they recently decided to embrace or ignore e-learning technology in the teaching process .

In this essence, it is essential to investigate how learners perceive and react to e-learning along with how to harness this technology effectively to boost their learning practice (Alobiedat \& Saraierh, 2010; Koohang \& Durante, 2003) where learners' positive attitude towards e-learning may provide useful insight about integrating technology into teaching and learning process successfully. 
Citation: Khalid Ramadan, et al., An Analysis of Factors affecting Learners' attitudes towards the Integration of E-learning into the Higher Education System in Libya: Case Study; Misurata University. Australian Journal of Basic and Applied Sciences, 13(10): 55-64. DOI: 10.22587/ajbas.2019.13.10.8

\subsection{Attitudes, Awareness, and perceptions of Learners in Developing Nations}

It is generally argued that the amalgamation of e-learning technology has been highly influenced by numerous perspectives and enablers. Those challenges and aspects are linked to the essential issue regarding the acceptance and effectiveness of delivering instructional materials and teaching activities as well as end-user satisfaction chiefly the educators and the trainees( Kasse and Balunywa, 2013; Pilli et al.,2014). In the same token, Al- Adwan stated that stakeholders' commitment and the enduser acceptance to e-learning technology as well as their satisfaction are the most fundamental phase for producing a productive learning environment (Al-Adwan et al., 2013). Additionally, strong support can be found for this argument by Rhema \& Miliszewska who reported that "Student attitudes and beliefs towards e-learning, as well as their satisfaction with technology and past e-learning experiences are regarded as success determinants of future e-learning "( Rhema \& Miliszewska ,2014, p.169).

Recently, the e-learning system is increasingly being used in HEIs as a modern technology model that helps meet studentcentred learning paradigm However, many HEIs worldwide use the e-learning system but they still need to understand at the end the user acceptance process to this technology (Pilli et al.,2014).

According to (Bhuasiri et al., 2012) who maintained that critical success factors for harnessing e-learning in developing nations were associated with some factors including raising stakeholders' awareness for technology adoption, enhancing their perceptions and attitudes toward e-learning. In this context, investigating students' perceptions and attitudes toward e-learning and also the impact of demographic characteristics on their attitudes are considered to be a meaningful stage before thoroughly embarking online learning practices in educational activities (Chen, 2010; Park, 2009; Xhaferi, G., Bahiti, R., \& Farizi, 2018).

Regarding developing countries, research undertaken in the domain of learners' perceptions attitudes seem to show that students had positive attitudes towards the harness of ICT in teaching and learning environment. In line with this, (El Gamal \& El Aziz, 2011) declared that learners possess numerous attitudes towards e-learning; however, commonly are positive perceptions and attitudes. This was stressed by Nassoura (2012) and Zabadi and Al-Alawi (2016) who stated that the majority of learners own positive attitudes toward the e-learning because it raised students' motivations positively (Nassoura, 2012; Zabadi and Al-Alawi, 2016). Additionally, as pointed out by (Othman, Pislaru et al. 2013a) who stated that learners possess positive attitude toward the usage online learning setting where majority of them were contented with this practice. Additionally, Xhfari et al. (2018) stated that learners' attitudes chiefly depend on the level access to ICT facilities as well as attributed by their prior experience and skills with ICT and e-learning. However, the demographic characteristics and ICT experience and skills are recognized as a significant determinant to the learners' perception; therefore, understanding users' characteristics and e-learning systems usage is necessary to embark on effective e-learning initiative (Zabadi \& Al-Alawi, 2016). Thus, most researchers focused on investigating learners' demographical variables regarding their gender, and technology experience and skill (Zabadi \& Al-Alawi, 2016).

Reviewing the literature, prior related studies show that there is a rareness of researches about student's individual personal differences such as discipline and English proficiency, especially in developing nations. On this basis, this study wishes to fallout this void in similar literature. Thus, it was undertaken to examine the impact of demographic characteristics of learners on the attitudes toward e-learning including academic significant and English proficiency.

\section{METHODOLOGY}

The study was conducted to empirically investigate the influences and dissimilarities of students' demographic factors on their attitude towards e-learning amalgamation at MU by surveying 407 learners from various faculties at MU. Accordingly, participants were invited to answer an online questionnaire. To achieve the study aims, the questionnaire was designed on the basis of a five-point Likert scale. The collected data was analyzed using Statistical Package for Social Sciences (SPSS) to examine the relationships between their attitudes and their demographic characteristics. Also, descriptive statistics were used to summarize and describe the data collected from the participants.

\subsection{Data collection stage}

An online survey questionnaire was launched and distributed to the students to assess their attitudes towards e-learning and to find out any demographic factors that are significant towards the learners' use of e-learning. The sample size under study involved students from different program studies from all the major faculties of MU. The format of the questionnaire, used in this study enabled participants to select one of the following alternatives:"1"'strongly disagree',"2" 'disagree',"3" 'neutral', "4" 'agree',"5" 'strongly agree', to indicate to what extent they are satisfied with each statement related to their attitude towards e-learning.

The first section of results discusses learners' demographic characteristics. The second section examines the perception of students towards e-learning. Finally, an analysis of the effect of demographic information on the perception of students towards elearning and the relationships between the appointed variables are reported.

\subsection{Statistical analysis}

In order to investigate the research hypothesis, the responses of 407 participants were collected using an online questionnaire, and then analyzed using the Statistical Package for Social sciences (SPSS).

To check the independence between the gender of students and the attitude towards e-learning Chi-square was applied. And then the Person correlation test was applied to check the association among the different variables such as participants age, ICT use, English proficiency and academic major.

\section{RESULT}

This study used a survey method to examine the perception of MU learners towards e-learning. 
Citation: Khalid Ramadan, et al., An Analysis of Factors affecting Learners' attitudes towards the Integration of E-learning into the Higher Education System in Libya: Case Study; Misurata University. Australian Journal of Basic and Applied Sciences, 13(10): 55-64. DOI: 10.22587/ajbas.2019.13.10.8

The first section discusses students' demographic characteristics, i.e. gender, age, English proficiency, computer use and academic sector. The second section examined the perception of students towards e-learning. Finally, analysis the effect of demographic profile on the knowledge of students towards e-learning.

\section{A. Demographic Profile of Learners}

The total number of participants was 407 students from all the principal faculties of MU. The results revealed that the dominance of males is quite clear about (66.59\%). Data on the age, a vast majority (88.21\%) of the participating students fell in the age group between $21-25$ years. The result also revealed that there were $(52.82 \%)$ students possess the intermediate level of language proficiency. In terms of academic discipline, the highest percentage of respondents around (59.46\%) belong to scientific discipline. Further information on students' computer use, showed that there were (44.47\%) students with computer use experience less than 10 years and (51.59\%) students with computer use experience ranging from 11 to 20 years whereas (3.94\%) more than 20 years of computer use experience. Table 1 shows the demographic characteristics of the participants.

Table 1: Demographic Statistics of participating learners

\begin{tabular}{|c|c|c|c|}
\hline Demographic Characteristics & Descriptive Statistics & Respondents & Percentage \% \\
\hline \multirow{2}{*}{ Academic sector } & Science & 242 & $59.46 \%$ \\
\cline { 2 - 4 } & Arts & 165 & $40.54 \%$ \\
\hline \multirow{2}{*}{ Gender } & Total & 407 & \\
\hline \multirow{3}{*}{ Age } & Male & 271 & $66.59 \%$ \\
\cline { 2 - 4 } & Female & 136 & $33.41 \%$ \\
\hline \multirow{3}{*}{ English Proficiency } & Total & 407 & \\
\hline & Less than 20 & 28 & $6.87 \%$ \\
\cline { 2 - 4 } & Between 21-25 & 359 & $88.21 \%$ \\
\cline { 2 - 4 } & More than 25 & 20 & $4.92 \%$ \\
\cline { 2 - 4 } & Total & 407 & \\
\cline { 2 - 4 } & Elementary & 132 & $32.43 \%$ \\
\hline \multirow{3}{*}{ Computer Use } & Advanced & 60 & $52.82 \%$ \\
\hline & Total & 407 & $14.75 \%$ \\
\hline & Less than 10 & 181 & $44.47 \%$ \\
\cline { 2 - 4 } & Between $11-20$ & 210 & $51.59 \%$ \\
\hline & More than 20 & 16 & $3.94 \%$ \\
\hline
\end{tabular}

\section{A. Learners' perception}

The participants were first asked to respond whether they support the application of e-learning in the subjects that they are studying or not.

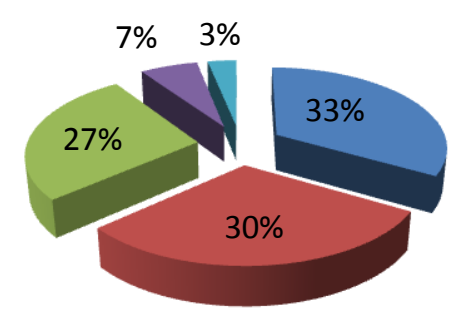

Strongly Agree
Agree
Neutral
Disagree
Strongly Disagree

Figure 1: participants' perception of supporting the implementation of e-learning

The Figure 1 shows that (33\%) of participants responded with strongly agree, and (30\%) responded with "agree" was in favor of implementing e-learning in the educational process, while only (7\%) of learners were not interested in it. This result underlines that most of the participants were keen to use e-learning in their courses.

This study is also inquired about the response of students towards using e-learning as a tool will increase the efficiency of their teaching experience through interacting outside of class with both teachers and colleagues online. 


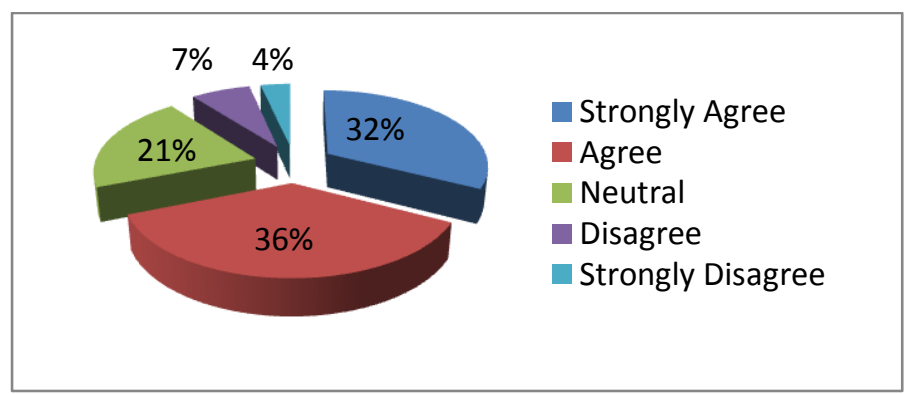

Figure: 2 learners' response towards using e-learning as a tool for teaching will increase the efficiency of their teaching experience

This result indicates that most of the learners $(68 \%)$ believed that using e-learning as a tool for teaching would increase the efficiency of their educational experience. In terms of learners' perceptions regarding the impact of using online resources on their performance, the participants were asked whether they think that the use of e-learning has a positive effect on their performance.

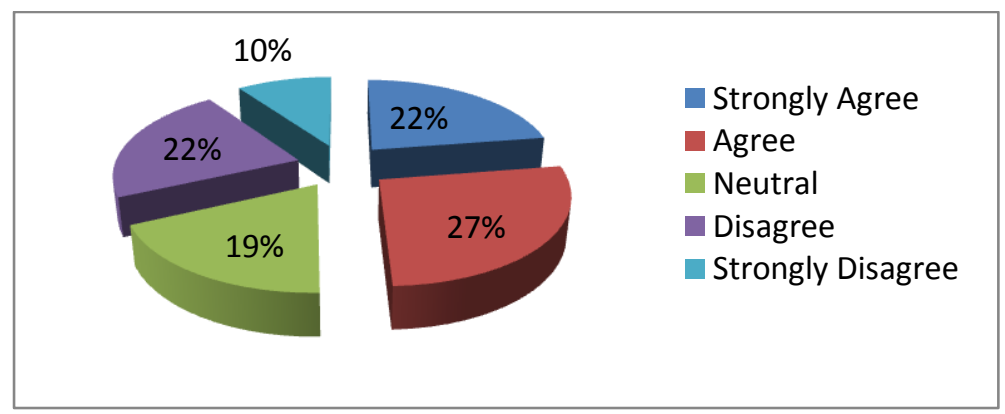

Figure 3: the use of e-learning has a positive effect on the performance of the student

As it is seen, Figure 3 shows that (49\%) of participants admit that e-learning has a positive influence on students' performance, whereas only (32\%) felt that e-learning has no positive effect on their performance in learning. Concerning student engagement, the learners were asked whether the use of online resources will make them more engaged in the educational process.

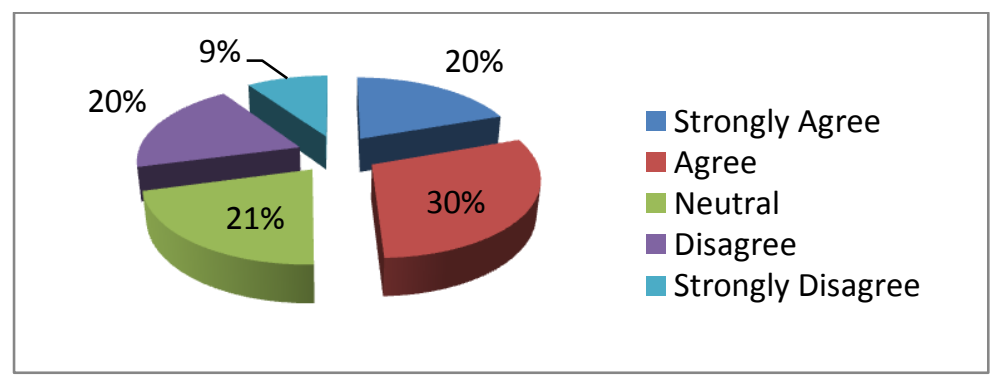

Figure 4: the use of e- e-learning makes the students more engaged in the education process

Statistics in Figure 4 indicate that half of the participants think that e-learning makes the students more engaged in the education process, while only (29\%) of learners disagree with this statement.

Regarding students' beliefs about using online resources for delivering courses, the participants were asked whether the use of e-learning is more flexible and enable students to understand the topic in hand better than the traditional teaching style.

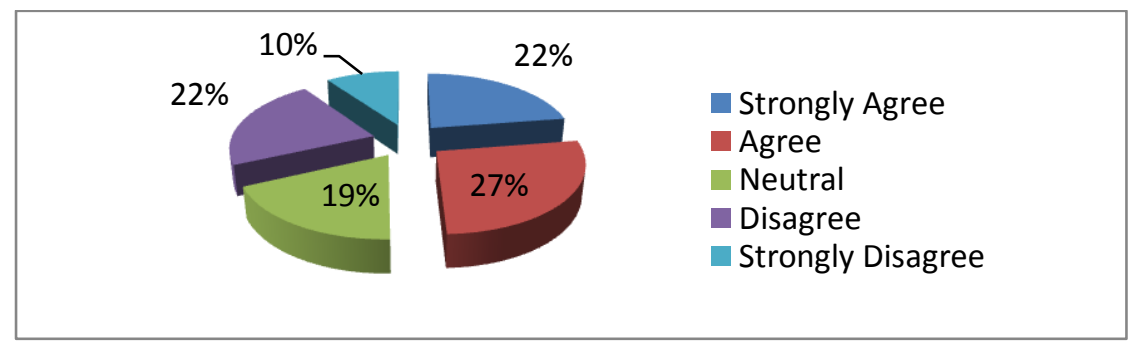

Figure 5: the use of e- e-learning is more flexible than the traditional way of teaching

As illustrated in Figure 5 (49\%) of learners declared that using e-learning can be more flexible than the traditional way of teaching. Only (32\%) did not believe that e-learning is not more flexible than the traditional way of teaching. 
Citation: Khalid Ramadan, et al., An Analysis of Factors affecting Learners' attitudes towards the Integration of E-learning into the Higher Education System in Libya: Case Study; Misurata University. Australian Journal of Basic and Applied Sciences, 13(10): 55-64. DOI: 10.22587/ajbas.2019.13.10.8

Finally, the participants were asked whether they believe that e-learning could contribute to solving some of the educational problems (such as access to distance learning materials, increases students' access to education, etc.)

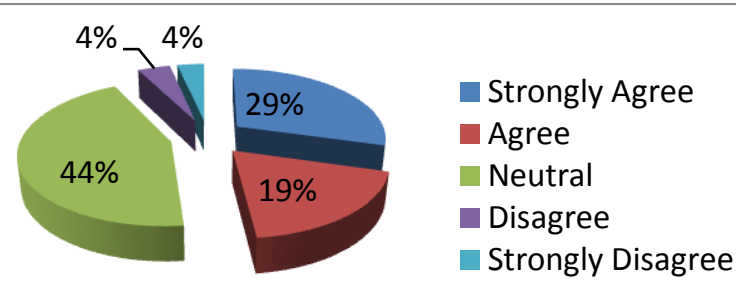

Figure 6: the use of e-learning can contribute to solving some educational problems

The results suggested that of (48\%) students believed that e-learning could contribute to solving some educational problems. However, (44\%) of students were still undecided and only a small number i.e. (8\%) responded negatively.

\section{Assessing the association between IVs and attitude towards e-learning adoption}

As the second research question was, "Is there any association between the demographic profile of learners and their attitude towards e-learning?" In this context, the present section analyses whether there is any significant difference in the students' attitudes towards online learning based on their demographic profiles i.e., age, gender, ICT use, the field of study and English language proficiency. Chi-square and Person correlation statistical tests were applied to explore the correlation and independence of variables.

\section{i. Gender and students' attitudes toward e-learning}

This section of the study investigates whether there is a significant association between the gender of participants and using an e-learning by exploring the following hypotheses:

$\mathrm{H}_{0}$ : There is no significant association between the gender of participants and their attitudes using e-learning.

$\mathrm{H}_{1}$ : There is a significant association between the gender of participants and using e-learning.

Table 2: Gender and students' attitudes toward e-learning

\begin{tabular}{|c|c|c|c|c|c|}
\hline \multicolumn{6}{|c|}{ Chi-Square Tests } \\
\hline & Value & df & Asymp. Sig. (2-sided) & Exact Sig. (2-sided) & Exact Sig. (1-sided) \\
\hline Pearson Chi-Square & $.123 \mathrm{a}$ & 1 & .725 & & \\
\hline Continuity Correction & .060 & 1 & .807 & & \\
\hline Likelihood Ratio & .124 & 1 & .725 & & \\
\hline Fisher's Exact Test & & & & .751 & .404 \\
\hline Linear-by-Linear Association & .123 & 1 & .726 & & \\
\hline $\mathrm{N}$ of Valid Cases & 407 & & & & \\
\hline \multicolumn{6}{|c|}{ a. 0 cells $(.0 \%)$ have expected count less than 5 . The minimum expected count is 55.65 . } \\
\hline . Computed only for a $2 \times 2$ table & & & & & \\
\hline
\end{tabular}

As shown in Table (2), the results confirm (H0), in that there was no significant association between the gender of participants and their attitudes towards using E-learning $(\mathrm{P}$.value $=.725)$.

\section{ii. Age and students' attitudes toward e-learning}

To investigate whether there is a significant correlation between the age of participants and using e-learning, the following hypotheses were explored using person correlation test.

$\mathrm{H}_{0}$ : There is no significant correlation between the age of participants and using e-learning

$\mathrm{H}_{1}$ : There is a significant correlation between the age of participants and using e-learning

Table 3: Age and learners' attitudes toward e-learning

Correlations

\begin{tabular}{|c|c|c|c|}
\hline \multicolumn{2}{|c|}{} & Age & Have You Ever Used E-learning \\
\hline \multirow{3}{*}{ Age } & Pearson Correlation & 1 & .016 \\
\cline { 2 - 4 } & Sig. (2-tailed) & & .750 \\
\cline { 2 - 4 } & $\mathrm{N}$ & 407 & 407 \\
\hline \multirow{3}{*}{ Have You Ever Used E-learning } & Pearson Correlation & .016 & 1 \\
\cline { 2 - 4 } & Sig. (2-tailed) & .750 & 407 \\
\cline { 2 - 4 } & $\mathrm{N}$ & 407 & 407 \\
\hline
\end{tabular}


Citation: Khalid Ramadan, et al., An Analysis of Factors affecting Learners' attitudes towards the Integration of E-learning into the Higher Education System in Libya: Case Study; Misurata University. Australian Journal of Basic and Applied Sciences, 13(10): 55-64. DOI: 10.22587/ajbas.2019.13.10.8

As shown in Table (3), the results prove the alternative hypothesis (H0), there was no significant correlation between the age of participants and using e-learning (P.value= .750)

\section{iii. ICT use and learners' attitudes toward e-learning}

This section of the study investigated whether there is a significant correlation between using e-learning and the years of computer use. The Pearson correlation test was conducted to explore the following hypotheses:

$\mathrm{H}_{0}$ : There is no significant association between using e-learning and years of computer use

$\mathrm{H}_{1}$ : There is a significant association between using e-learning and years of computer use

Table 4: Years of computer use and learners' attitudes toward e-learning

\begin{tabular}{|c|c|c|c|}
\hline \multicolumn{4}{|l|}{ Correlations } \\
\hline & & Computer Use & Have You Ever Used E-learning \\
\hline \multirow{3}{*}{ ComputerUse } & Pearson Correlation & 1 & $.328 * *$ \\
\hline & Sig. (2-tailed) & & .000 \\
\hline & $\mathrm{N}$ & 407 & 407 \\
\hline \multirow{3}{*}{ Have You Ever Used E-learning } & Pearson Correlation & $.328 * *$ & 1 \\
\hline & Sig. (2-tailed) & .000 & \\
\hline & $\mathrm{N}$ & 407 & 407 \\
\hline
\end{tabular}

As shown in Table (4), the results affirm the hypothesis (H1), there was a significant correlation between the years of computer use and using e-learning $(r=0.328$ and p.value $=000)$

\section{iii. Academic dominant and students' attitudes toward e-learning}

This section of the study investigates whether there is a significant association between the academic discipline of the participant and using e-learning.

Table 5: Academic major and learners' attitudes toward e-learning

\section{Correlations}

\begin{tabular}{|c|c|c|c|}
\hline \multicolumn{4}{|c|}{ Correlations } \\
\hline & & Department & Have You Ever Used E-learning \\
\hline \multirow{3}{*}{ Department } & Pearson Correlation & 1 & $.510^{* *}$ \\
\hline & Sig. (2-tailed) & & .000 \\
\hline & $\mathrm{N}$ & 407 & 407 \\
\hline \multirow{3}{*}{ Have You Ever Used E-learning } & Pearson Correlation & $.510^{* * *}$ & 1 \\
\hline & Sig. (2-tailed) & .000 & \\
\hline & $\mathrm{N}$ & 407 & 407 \\
\hline
\end{tabular}

As shown in Table (5), the results revealed that there was a significant association between the disciplines of participants and using E-learning $(r=0.510$ and p.value=000)

\section{vi. English language proficiency and students' attitudes toward e-learning}

The study needed to get more insights into the LHEIs, if there was a statistically significant correlation in attitudes towards elearning between learners' perception and their level of English language.

Table 6: English language proficiency and students' attitudes toward e-learning

\section{Correlations}

\begin{tabular}{|c|c|c|c|}
\hline \multicolumn{4}{|l|}{ Correlations } \\
\hline & & Proficiency & Have You Ever Used E-learning \\
\hline \multirow{3}{*}{ Proficiency } & Pearson Correlation & 1 & $.459 * *$ \\
\hline & Sig. (2-tailed) & & .000 \\
\hline & $\mathrm{N}$ & 407 & 407 \\
\hline \multirow{3}{*}{ Have You Ever Used E-learning } & Pearson Correlation & $.459 * *$ & 1 \\
\hline & Sig. (2-tailed) & .000 & \\
\hline & $\mathrm{N}$ & 407 & 407 \\
\hline
\end{tabular}

The results, as shown in the above table, reveals that there was a significant correlation between English language proficiency and using E-learning ( $\mathrm{r}=0.459$ and p.value= 000). 
Citation: Khalid Ramadan, et al., An Analysis of Factors affecting Learners' attitudes towards the Integration of E-learning into the Higher Education System in Libya: Case Study; Misurata University. Australian Journal of Basic and Applied Sciences, 13(10): 55-64. DOI: 10.22587/ajbas.2019.13.10.8

\section{DISCUSSION}

As formidable support in the literature is available that has affirmed that the successful adoption of e-learning system is heavily relying on the right and favourable attitudes of the learners (Farahat, 2012; Ghenghesh, Croxford, Nagaty, \& Abdelmageed, 2018; Kar, Saha, \& Chandra Mondal, 2014; Peytcheva-Forsyth, Yovkova, \& Aleksieva, 2018; Sebnem, 2015). Moreover, understanding students' demographic profiles is necessary to introduce an effective e-learning initiative ( Xhaferi, G., Bahiti, R., \& Farizi, 2018; Zabadi \& Al-Alawi, 2016; Žuvić-Butorac, et al.,2011). Additionally, Cheng (2006) maintained that individual profile information such as gender, ICT skills are not sufficient when studying the students' perception concerning elearning application. On this basis, the present study was undertaken to examine the impact of demographic characteristics on the learners' perception and attitudes towards using e-learning in the process of learning. These characteristics included: the academic discipline and English proficiency.

Generally, the findings revealed that the students in MU had positive attitudes towards e-learning where demographic profile played a statistically significant contribution to their attitudes. The results of this study were consistent with a number of similar previous work (Abod-her, 2013; Bendania, 2011; Concannon, Flynn, \& Campbell, 2005; Elzawi, A., Wade, S., Kenan, T., \& Pislaru, 2013; Ghenghesh et al., 2018; Kar et al., 2014; S. S. Liaw et al., 2007; Mahmoud, S. R., El Magrabi, N. M., \& Mohamed, 2015; Ransom, Graham, \& Mott, 2007; Reading, 2008; Zabadi \& Al-Alawi, 2016).

An interesting outcome is that the academic discipline appears to perform a pivotal factor in affecting the level of perception as there was a significant difference regarding learner's attitude towards e-learning based on academic major. It was found that the science department was more likely to adopt e-learning in their teaching than their counterparties, i.e. art discipline. This outcome contrast with (Jayaraj \& Nirmal, 2018; Kar et al., 2014; Phillips, 2013) who found that students' perceptions did not vary significantly with their major of study.

Another interesting finding is regarding English proficiency. The results revealed that there was a significant difference between learners' elementary level and students' advanced level. This particular finding could provide new insights into the role of English level on attitudes toward e-learning, particularly in countries that the English language is the second language.

Data on age further indicated that students' age remained insignificant. Result contrast with (Kar et al., 2014; Peytcheva-Forsyth et al., 2018; Zabadi \& Al-Alawi, 2016). As most of the prior studies on age difference in attitudes towards use of e-learning materials have shown that significant differences among the learners were based on age. This conflict may be ascribed to the fact that those studies were conducted with various samples of participants with different cultures in a different environment and context.

Results further indicated that learners' skills and experience with ICT might significantly impact on attitude towards online learning where it represented a noteworthy role in constructing positive attitudes towards e-learning. This statement also supports outcomes from previous researches ( Liaw \& Huang, 2011; Peytcheva-Forsyth et al., 2018; Zabadi \& Al-Alawi, 2016).

Finally, the study examined the influence of gender where disclosed that there was no significant difference between the participants' attitudes involved in the present study. This result is consistent with previous work (Cheng, 2006; Ghenghesh et al., 2018; Kar et al., 2014; Sebnem, 2015; Suri \& Sharma, 2013; Žuvić-Butorac, et al.,2011).These studies disclosed that the gap between male and female in the variation in perceptions towards e-learning was declined.

\section{CONCLUSION}

In conclusion, the result of this study reveals that students at MU are willing to adopt e-learning. The findings also reaffirm that the demographic characteristics of students have highly contributed toward the formation of the learners' perspectives in the educational setting, in particular, ICT skills and experience, academic department, and English proficiency. Further, the results suggest that well understanding those factors are contributory for developing an interactive platform that may boost students' knowledge and would make the learning experience more effective and appealing.

\section{REFERENCE}

Abod-her. (2013). Impacts of globalisation and awareness of higher education policy in adoption and use of ICT in Libyan universities (Doctoral dissertation, University of Huddersfield).

Ahmed, T. T. (2013). Toward Successful E-Learning Implementation in Developing Countries: A Proposed Model for Predicting and Enhancing Higher Education Instructors' Participation. International Journal of Academic Research in Business and Social Sciences, 3(1), 2222-6990.

Al-Adwan, A., Al-Adwan, A., \& Smedley, J. (2013). Exploring students acceptance of e-learning using Technology Acceptance Model in Jordanian universities, 9(2013), 4-18. https://doi.org/10.1504/IJHTM.2015.074538

Al-Azawei, A., Parslow, P., \& Lundqvist, K. (2016). Barriers and opportunities of e-learning implementation in Iraq: A case of public universities. International Review of Research in Open and Distance Learning, 17(5), 126-146. https://doi.org/10.19173/irrodl.v17i5.2501

Al-Gahtani, S. S. (2016). Empirical investigation of e-learning acceptance and assimilation: A structural equation model. Applied Computing and Informatics, 12(1), 27-50. https://doi.org/10.1016/j.aci.2014.09.001

Almansuri, A. A., \& Elmansuri, R. A. (2015). Utilizing E-learning systems in the Libyan universities: Case study; Tripoli University, faculty of engineering. Proceedings of the International Conference on E-Learning 2015, E-LEARNING 2015 Part of the Multi Conference on Computer Science and Information Systems 2015, 188-192. 
Citation: Khalid Ramadan, et al., An Analysis of Factors affecting Learners' attitudes towards the Integration of E-learning into the Higher Education System in Libya: Case Study; Misurata University. Australian Journal of Basic and Applied Sciences, 13(10): 55-64. DOI: 10.22587/ajbas.2019.13.10.8

Alobiedat, A., \& Saraierh, R. (2010). The student's attitude toward use platform as learning resources at university of Granada. Review of European Studies, 2(2), 236-244. https://doi.org/10.5539/res.v2n2p236

Alzain, A. M., Clark, S., \& Ireson, G. (2014). Libyan Higher Education system, challenges and achievements. In ICEED 2014 2014 IEEE 6th Conference on Engineering Education (pp. 67-72). https://doi.org/10.1109/ICEED.2014.7194690

Andersson, A., \& Grönlund, Å. (2009). A Conceptual Framework for E-Learning in Developing Countries: A Critical Review of Research Challenges. The Electronic Journal of Information Systems in Developing Countries, 38(1), 1-16. https://doi.org/10.1002/j.1681-4835.2009.tb00271.x

Bendania, A. (2011). INSTRUCTORS' AND LEARNERS' ATTITUDES TOWARD TEACHING AND LEARNING ONLINE: KING FAHD UNIVERSITY OF PETROLEUM AND MINERALS (KFUPM) (SAUDI ARABIA) CASE STUDY ProQuest. International Journal of Arts and Sciences, 4(8), 223-241.

Bhuasiri, W., Xaymoungkhoun, O., Zo, H., Rho, J. J., \& Ciganek, A. P. (2012). Critical success factors for e-learning in developing countries: A comparative analysis between ICT experts and faculty. Computers and Education, 58(2), 843-855. https://doi.org/10.1016/j.compedu.2011.10.010

Chen, H. J. (2010). Linking employees'e-learning system use to their overall job outcomes: An empirical study based on the IS success model. Computers \& Education, 55(4), 1628-1639.

Cheng, K. (2006). A Research Study on Students' Level of Acceptance in Applying E-learning for Business Course. A Case Study on a Technical College in Taiwan", Journal of American Academy of Business, 8(2), 265-272.

Concannon, F., Flynn, A., \& Campbell, M. (2005). What campus-based students think about the quality and benefits of e-learning. British Journal of Educational Technology, 36(3), 501-512. https://doi.org/10.1111/j.1467-8535.2005.00482.x

Cowen, J. B. (2009). the Influence of Perceived Usefulness,Perceived Ease of Use,and Subjective Norm on the Use of Comuted Radiography Systems.

Eke Helen Nneka. (2011). Modeling LIS student's intention to adopt e-learning: a case from University of Nigeria, Nsukka. Library Philosophy and Practice, (September).

El Gamal, S., \& El Aziz, R. A. (2011). An Investigation of the Effect of Higher Education Student' s Perception on their Readiness for E-Learning Adoption: The Case of Egypt. International Conference on E-Learning, e-Business, Enterprise Information Systems, and e-Government.

Elzawi, A., Wade, S., Kenan, T., \& Pislaru, C. (2013). Exploratory study of the attitudes of academic staff in Libyan Universities towards the role of the Internet. 8th International Conference for Internet Technology and Secured Transactions (ICITST2013) (Pp. 490-493). IEEE, 490-493.

Farahat, T. (2012). Applying the Technology Acceptance Model to Online Learning in the Egyptian Universities. Procedia Social and Behavioral Sciences, 64, 95-104. https://doi.org/10.1016/j.sbspro.2012.11.012

Ghenghesh, P., Croxford, L., Nagaty, K., \& Abdelmageed, S. (2018). Students and Teachers Attitudes and Satisfaction Toward ELearning: A Case Study in Egypt The Journal of Middle East and North Africa Sciences 2018 ; 4 ( 01 ), 4(01), 15-31.

Goodwin, R., \& Al-hunaiyyan, A. (2008). Students ' Attitudes Toward E-learning in Kuwait ' s Higher Education Institutions Students' Attitudes Toward E-learning in Kuwait's Higher Education Institutions, (January), 841-848.

Idris, F. elmoula A. alla, \& Osman, Y. (2017). Implementation of E-learning in The University of Gezira Barriers and Opportunities. Educational Science and Research, 1(1), 24-35. https://doi.org/10.22496/esr2016090470

Jamlan, M. (2004). Faculty opinions towards introducing e-learning at the University of Bahrain. International Review of Research in Open and Distance Learning, 5(2).

Jayaraj, K., \& Nirmal, V. (2018). The usage of internet and e- learning practice among the college students with special reference to Hindusthan College of Arts and Science, Coimbatore, 5(2), 72-88.

Kar, D., Saha, B., \& Chandra Mondal, B. (2014). Attitude of University Students towards E-learning in West Bengal. American Journal of Educational Research, 2(8), 669-673. https://doi.org/10.12691/education-2-8-16

Kashada, A., Li, H., \& Koshadah, O. (2018). Analysis Approach to Identify Factors Influence Digital Learning Technology Adoption and Utilization in Developing Countries. International Journal of Emerging Technologies in Learning, 13(2), 48-59. https://doi.org/10.3991/ijet.v13i02.7399

Kasse, J. P., \& Balunywa, W. (2013). An assessment of e-learning utilization by a section of Ugandan universities : challenges , success factors and way forward. International Conference on ICT for Africa 2013, 15.

Kenan, T., \& Pislaru, C. (2012). Challenges related to the implementation of e-learning in higher education institutions in Libya. In Proceedings of The Queen's Diamond Jubilee Computing and Engineering Annual Researchers' Conference 2012: CEARC'12. (pp. 116-122).

Kenan, T., Pislaru, C., \& Elzawi, A. (2012). Analysing the effectiveness of e-learning based on national and international cultures and approaches to pedagogy. In 17th UKAIS Conference on Information Systems, Oxford University.

Kisanga, D., \& Ireson, G. (2015). Barriers and strategies on adoption of e - learning in Tanzanian higher learning institutions : Lessons for adopters. International Journal of Education and Development Using Information and Communication Technology, 11(2), 126-137.

Koohang, A., \& Durante, A. (2003). Learners' Perceptions toward the Web-based Distance Learning Activities/Assignments Portion of an Undergraduate Hybrid Instructional Model. Journal of Information Technology Education: Research, 2. https://doi.org/10.28945/316

Liaw, S., \& Huang, H.--mei. (2011). A study of investigating learners attitudes toward e-learning. The Fifth International Conference on Distance Learning and Education, 12(September), 28-32.

Liaw, S. S., Huang, H. M., \& Chen, G. D. (2007). Surveying instructor and learner attitudes toward e-learning. Computers and Education, 49(4), 1066-1080. https://doi.org/10.1016/j.compedu.2006.01.001 
Citation: Khalid Ramadan, et al., An Analysis of Factors affecting Learners' attitudes towards the Integration of E-learning into the Higher Education System in Libya: Case Study; Misurata University. Australian Journal of Basic and Applied Sciences, 13(10): 55-64. DOI: 10.22587/ajbas.2019.13.10.8

Mahmoud, S. R., El Magrabi, N. M., \& Mohamed, F. R. (2015). Faculty of Nursing Teaching Staff members and Students Attitudes toward e-learning. IOSR Journal of Nursing and Health Science, 4(4), 2320-1940. https://doi.org/10.9790/195904463645

Mwakyusa, W. P., \& Mwalyagile, N. V. (2016). Impediments of E-Learning Adoption in Higher Learning Institutions of Tanzania: An Empirical Review. Journal of Education and Practice, 7(30), 152-160.

Othman, A., Pislaru, C., Kenan, T., \& Impes, A. (2013a). Analysing the Effectiveness of IT Strategy in Libyan Higher Education Institutes. International Journal of Digital Information and Wireless Communications (IJDIWC), 3(3), 114-129.

Othman, A., Pislaru, C., Kenan, T., \& Impes, A. (2013b). Attitudes of Libyan Students Towards Ict ' S Applications and ELearning in the Uk. Isbn, 123-129. https://doi.org/10.1016/B978-0-323-22158-0.00003-2

Park, S. Y. (2009). An Analysis of the Technology Acceptance Model in Understanding University Students' Behavioral Intention to Use e-Learning. Journal of Educational Technology \& Society, 12(3), 150-162. https://doi.org/10.2307/jeductechsoci.12.3.150

Peytcheva-Forsyth, R., Yovkova, B., \& Aleksieva, L. (2018). Factors affecting students' attitudes towards online learning - The case of Sofia University. In AIP Conference Proceedings (Vol. 2048). https://doi.org/10.1063/1.5082043

Phillips, M. S. (2013). Instructor and Student Perceptions of Online Courses: Implications of Positioning Theory.

Pilli, F. \& A.-M. (2014). Investigating the Students 'Attitude Toward the use of E-Learning in Girne American University. International Journal of Business and Social Science, 5(5), 169-175.

Rahamat, R., Shah, P. M., \& Din, R. (2012). Measuring Learners ' Perceived Satisfaction Towards e-Learning Material and Environment. WSEAS Transactions on Advances in Engineering Education, 9(3), 72-83.

Ramadan, K., Elatresh, J., Alzain, A., \& Tokeser, U. (2019). Investigating Instructors 'Attitude towards the Adoption of E Learning Technology in Libyan Higher Education Institutes: Case Study; Misurata University, 13(5), 43-54. https://doi.org/10.22587/ajbas.2019.13.5.5

Ransom, W., Graham, C., \& Mott, J. (2007). Faculty perceptions of technology projects. Educause Quarterly.

Reading, C. (2008). Recognising and measuring engagement in ICT-rich learning environments. Australian Council for Computers in Education.

Rhema, A., \& Miliszewska, I. (2010). Towards E-Learning in Higher Education in Libya. Issues in Informing Science and Information Technology, 7, 423-437. https://doi.org/10.28945/1218

Saade, R., Nebebe, F. \& Tan, W. (2007). Viability of the "Technology Acceptance Model" in Multimedia Learning Environments: A Comparative Study. Interdisciplinary Journal of E-Skills and Lifelong Learning, 3, 175-184. https://doi.org/10.28945/392

Sebnem, K. I. (2015). Investigation of students attitudes towards e-learning in terms of different variablesA case study in a technical and vocational high school for girls. Educational Research and Reviews, 10(1), 81-91. https://doi.org/10.5897/ERR2014.1980

Selim, H. M. (2007). Critical success factors for e-learning acceptance: Confirmatory factor models. Computers and Education, 49(2), 396-413. https://doi.org/10.1016/j.compedu.2005.09.004

Sife, A. T., Lwoga, E. T., Sanga, C., \& Sife, A., Lwoga, E., \& Sanga, C. (2007). New technologies for teaching and learning: Challenges for higher learning institutions in developing countries. International Journal of Education and Development Using Information and Communication Technology, Vol. 3(2), 57-67.

Suri, G., \& Sharma, S. (2013). The Impact of Gender on Attitude Towards Computer Technology and E- Learning: An Exploratory Study of Punjab University, India. International Journal of Engineering Research, 2(2319-6890), 22.

Tamtam, A., Gallagher, F., Olabi, A. G., \& Naher, S. (2011). Higher education in Libya, system under stress. In Procedia - Social and Behavioral Sciences (Vol. 29, pp. 742-751). https://doi.org/10.1016/j.sbspro.2011.11.300

Tarhini, A., Elyas, T., Akour, M. A., \& Al-Salti, Z. (2016). Technology, Demographic Characteristics and E-Learning Acceptance: A Conceptual Model Based on Extended Technology Acceptance Model. Higher Education Studies, 6(3), 72. https://doi.org/10.5539/hes.v6n3p72

Woodrow, J. E. J. (1990). Locus of control and student teacher computer attitudes. Computers \& Education, 14(5), 421-432. https://doi.org/10.1016/0360-1315(90)90036-7

Xaymoungkhoun, O., Bhuasiri, W., Rho, J. J., Zo, H., \& Kim, M. G. (2012). The critical success factors of e-learning in developing countries. Kasetsart Journal - Social Sciences, 33(2), 321-332.

Xhaferi, G., Bahiti, R., \& Farizi, A. (2018). The Impacts of Demographic Variables of students on attitudes towards e-learning in higher education, 16(6), 93-99.

Xhaferi, G., Bahiti, R., \& Farizi, A. (2018). Analysis of Students Factors Influencing the Integration of E-Learning in Higher Education. Case Study:University of Tetovo. European Journal of Formal Sciences and Engineering, 1(2), 33. https://doi.org/10.26417/ejfe.v1i2.p33-38

Zabadi, A. M., \& Al-Alawi, A. H. (2016). University Students' Attitudes towards E-Learning: University of Business \& Technology (UBT)-Saudi Arabia-Jeddah: A Case Study. International Journal of Business and Management, 11(6), 286. https://doi.org/10.5539/ijbm.v11n6p286

Zhang, D., Zhao, J., \& ... L. Z.-. (2004). Can e-learning replace classroom learning?. Pdfs.Semanticscholar.Org.

Žuvić-Butorac, M., Rončević, N., Nemčanin, D., \& Nebić, Z., \& Žuvic-Butorac, M. (2011). Blended E-Learning in Higher Education: Research on Students' Perspective. Informing Science Institute429-409,8 ,. 